\title{
Improving IPS Learning Outcomes Community Economy Material Through Class IV Demonstration Methods Sd Negeri 2 Gambarsari
}

\author{
Khanif Mutobiq \\ SD Negeri 2 Gambarsari \\ hmoetobique@gmail.com
}

\section{Article History}

accepted 01/11/2020

\begin{abstract}
This research is an effort to improve learning outcomes, because the learning outcomes of grade IV SD Negeri 2 Gambarsari in the formative test of social studies learning material on community economic activities. CAR is carried out in 3 cycles, namely cycle I, cycle II and cycle III. The stages of each cycle are planning, implementing, observing and reflecting. Data collection methods include observation, tests, and documentation. Data analysis was carried out by calculating the achievement of the learning outcomes of each cycle.
\end{abstract}

The results showed an increase in student learning outcomes for social studies subjects regarding community economic activities. Through the demonstration method there is an increase in learning outcomes, which is seen in the initial conditions, namely $13 \%$ of students who complete learning, in cycle I increases to $40 \%$, increases in cycle II to $93.33 \%$, and increases again in cycle III $100 \%$ of students complete. Based on these results, it was concluded that the demonstration method could improve social studies learning outcomes about community economic activities in grade IV SD Negeri 2 Gambarsari.

Keywords: Learning Outcomes, Social Studies, Demonstration Methods

\begin{abstract}
Abstrak
Penelitian ini merupakan upaya untuk meningkatkan hasil belajar, karena hasil belajar siswa kelas IV SD Negeri 2 Gambarsari berupa tes formatif materi pembelajaran IPS pada kegiatan ekonomi masyarakat. PTK dilaksanakan dalam 3 siklus yaitu siklus I, siklus II dan siklus III. Tahapan setiap siklus adalah perencanaan, pelaksanaan, observasi dan refleksi. Metode pengumpulan data meliputi observasi, tes, dan dokumentasi. Analisis data dilakukan dengan menghitung ketercapaian hasil belajar tiap siklus.
\end{abstract}

Hasil penelitian menunjukkan adanya peningkatan hasil belajar siswa pada mata pelajaran IPS mengenai kegiatan ekonomi masyarakat. Melalui metode demonstrasi terjadi peningkatan hasil belajar, yang terlihat pada kondisi awal yaitu $13 \%$ siswa yang tuntas belajar, pada siklus I meningkat menjadi $40 \%$, meningkat pada siklus II menjadi $93,33 \%$, dan meningkat lagi pada siklus III 100\% siswa selesai. Berdasarkan hasil tersebut dapat disimpulkan bahwa metode demonstrasi dapat meningkatkan hasil belajar IPS tentang kegiatan ekonomi masyarakat di kelas IV SD Negeri 2 Gambarsari.

Kata Kunci: Hasil Belajar, IPS, Metode Demonstrasi

Social, Humanities, and Education Studies (SHEs): Conference Series https://jurnal.uns.ac.id/shes

p-ISSN 2620-9284 e-ISSN 2620-9292 


\section{PENDAHULUAN}

Secara umum menurut kenyataan yang ada, pelajaran IPS merupakan pelajaran yang menjadi momok, pelajaran yang sangat ditakuti oleh siswa. Karena pelajaran IPS dianggap pelajaran yang sarat dengan banyak menguras energi untuk berfikir. Sedangkan dalam kehidupan sehari-hari IPS merupakan kebutuhan yang sangat diperlukan dalam berbagai kehidupan, artinya manusia hidup tidak terlepas dari IPS.

Berdasarkan hasil survei penulis pada hari Senin tanggal 5 Oktober 2020 bahwa dari 15 siswa hanya $2(13,33 \%)$ siswa yang mendapatkan nilai di atas KKM. Adapun KKM untuk pelajaran ilmu pengetahuan sosial yaitu 75 . Sedangkan $13(86,66 \%)$ siswa lainnya nilainya masih di bawah KKM. Padahal materi aktivitas ekonomi di masyarakat ini sangat erat kaitannya dengan kehidupan sehari-hari. Untuk itu siswa dituntut untuk memahami materi ini dengan benar.

Berdasarkan permasalahan di atas, maka penulis tertarik untuk melakukan penelitian mengenai hal tersebut. Oleh sebab itu, penulis ingin melakukan penelitian tindakan kelas (PTK) melalui judul : "Peningkatan Hasil Belajar IPS Tentang Kegiatan Ekonomi Di Masyarakat Melalui Metode Demonstrasi pada Siswa Kelas IV SD N 2 Gambarsari “. PTK atau class room action research pada dasarnya merupakan pengembangan dari konsep penelitian tindakan (action research). Berperan penting unntuk meningkatkan mutu pembelajaran apabila guru mencoba mengembangkan kemampuan memecahkan masalah-masalah yang terjadi dalam pembelajaran di kelas melalui tindakan yang dapat memecahkan masalah atau memperbaiki dan melakukan pengamatan untuk mengetahui tingkat keberhasilannya. PTK harus dimulai dari permasalahan yang dihadapi atas temuan hasil refleksi diri para guru untuk memperbaiki pelaksanaan pekerjaannya. Fokus PTK pada siswa atau proses pembelajaran yang terjadi di kelas. Kunandar $(2008 ; 45)$ menyebutkan ada tiga konsep atau unsur dalam penelitian tindakan kelas, yakni bahwa : Penelitian adalah aktivitas mencermati suatu objek tertentu melalui metodologi ilmiah dengan mengumpulkan data-data dan dianalisis untuk menyelesaikan suatu masalah. Kemudian $\mathrm{t}$ indakan adalah suatu aktivitas yang sengaja dilakukan dengan tujuan tertentu yang berbentuk siklus kegiatan dengan tujuan untuk memperbaiki atau meningkatkan mutu atau kualitas proses belajar mengajar serta Kelas adalah sekelompok siswa yang dalam waktu yang sama menerima pelajaran yang sama dari seorang guru.

Dari konsep ini dapat disimpulkan bahwa penelitian tindakan kelas merupakan sebuah prosesrefleksi diri yang dilakukan oleh guru dan perangkat pendidikan lainnya dalam situasi kependidikan yang bertujuan untuk memperbaiki: praktik-praktik kependidikan, pemahaman tentang praktik pendidikan itu sendiri dan dalam situasi bagaimana praktik tersebut dilaksanakan. Guru memperbaiki proses pengajarannya, kepala sekolah memperbaiki proses pengelolaan sekolah yang dipimpinnya, pengawas memperbaiki proses supervisi yang dilakukannya.

Sementara itu, Rumusan masalah dalam penelitian ini yaitu: "Apakah penerapan metode demonstrasi dapat meningkatkan hasil belajar IPS materi kegiatan ekonomi masyarakat pada siswa kelas IV SD Negeri 2 Gambarsari?" sedangkan tujuan penelitian ini adalah untuk meningkatkan hasil belajar IImu pengetahuan sosial (IPS) tentang kegiatan ekonomi masyarakat melalui penggunaan metode demonstrasi pada siswa kelas IV SD N 2 Gambarsari.

Kemudian manfaat penelitian ini sebagai berikut : Manfaat teoritis diantaranya penelitian ini berguna untuk meningkatkan hasil belajar siswa kelas IV SD $\mathrm{N} 2$ Gambarsari mata pelajaran ilmu pengetahuan sosial materi aktivitas ekonomi di masyarakat melalui metode demonstrasi . Sedangkan manfaat Praktisn bagi guru meliputi membantu guru dalam mengembangkan proses pembelajaran, guru menjadi lebih kreatif dalam mengemas dan menyampaikan pembelajaran serta memberikan inspirasi dalam penyampaian materi aktivitas ekonomi di masyarakat dengan menarik. Kemudian manfaat bagi siswa meliputi dapat meningkatkan hasil belajar ilmu pengetahuan sosial materi aktivitas ekonomi di masyarakat, memberikan pengalaman 
belajar yang menyenangkan, tidak mudah bosan kepada siswa, sehingga siswa akan lebih lama untuk mengingat materi, menumbuhkan motivasi belajar kepada siswa karena menggunakan metode dan media yang menarik. Sementara manfaat bagi lembaga adalah memberikan masukan untuk meningkatkan kualitas pendidikan melalui penggunaan media miniatur pada mata pelajaran IImu pengetahuan sosial.

\section{METODE}

Adapun lokasi subyek penelitian dalam perbaikan pembelajaran IPS berada di SD Negeri 2 Gambarsari Kecamatan Kebasen Kabupaten Banyumas, dimana peneliti mengajar di kelas IV di sekolah. sedangkanpPelaksanaan penelitian dilaksanakan dalam 3 siklus yaitu sebagai berikut: Siklus I dilaksanakan pada akhir bulan Oktober 2020, Siklus II dilaksanakan pada awal bulan November 2020 dan Siklus III dilaksanakan pada pertengahan bulan November 2020.

Pengumpulan data dilakukan dengan wawancara, observasi, dokumentasi, tes, dan catatan lapangan. SedangkantTeknik analisis data yang digunakan dalam penelitian ini adalah teknik analisis data deskriptif kualitatif. Yaitu menarik kesimpulan data-data yang diperoleh pada kondisi awal, siklus 1, dan siklus II yang berupa data kualitatif maupun data dari observasi yang dilakukan oleh pengamat/ kolabolator, dengan tahapan berikut: tahap pengumpulan data, tahap reduksi data, tahap penyajian data tahap penarikan kesimpulan. Dengan demikian data yang diperoleh dari tes I, tes II dan data pengamatan dengan lembar penilaian dianalisis secara kuantitatif. Perbandingan antara nilai rata-rata kelas dan simpangan baku antara tes I, tes II digunakan untuk mengetahui adanya peningkatan nilai. Jika nilai rata-rata kelas pada tes II lebih besar dari tes I dan pada tes II lebih kecil dari tes I dan tes II, maka ada peningkatan hasil belajar siswa dengan metode demonstrasi.

\section{HASIL DAN PEMBAHASAN}

Hasil penelitian yang dilakukan pada peserta didik kelas IV SD Negeri 2 Gambarsari, Kecamatan Kebasen, Kabupaten Banyumas terkait hasil belajar IPS tentang Kegiatan Ekonomi Masyarakat, melalui metode demonstrasi yang dilaksanakan dalam perbaikan pembelajaran pada siklus I, siklus 2 dan siklus 3 secara lengkap dijabarkan sebagai berikut

Tabel 1.1 Rekapitulasi Pra Siklus, Siklus I, dan Siklus II dan Siklus III

\begin{tabular}{cccc}
\hline Siklus & Kategori & Jumlah & Presentase \\
\hline Pra Siklus & Tuntas & 2 & $13 \%$ \\
& Tidak Tuntas & 13 & $87 \%$ \\
Siklus I & Tuntas & 6 & $40 \%$ \\
& Tidak Tuntas & 9 & $60 \%$ \\
Siklus II & Tuntas & 14 & $93 \%$ \\
& Tidak Tuntas & 1 & $7 \%$ \\
Siklus III & Tuntas & 15 & $100 \%$ \\
& Tidak Tuntas & 0 & $0 \%$ \\
\hline
\end{tabular}

Dari data di atas dapat diperjelas dengan gambar 1 : 


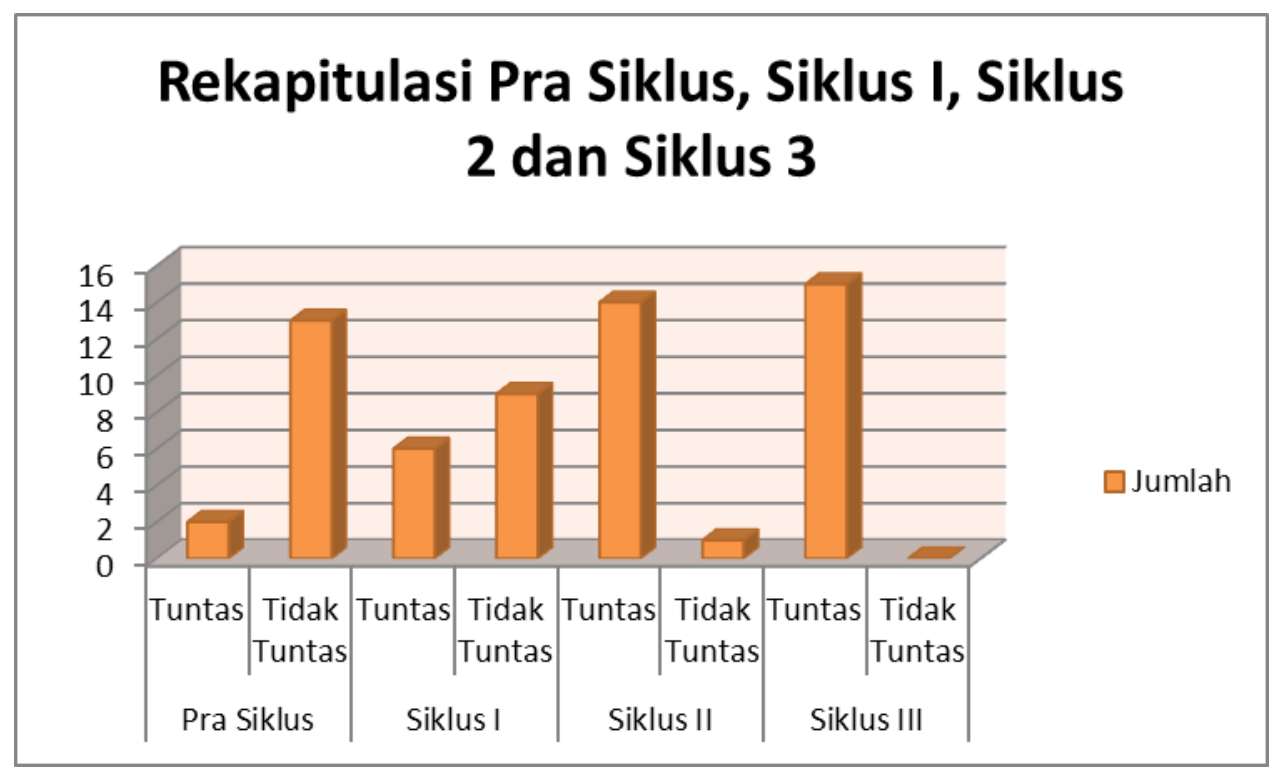

Gambar 1. Grafik Peningkatan pada siklus 1, 2 dan 3

Dari tabel dan grafik diatas dapat dijelaskan bahwa pada pembelajaran Prasiklus hasil belajar siswa kelas IV SDN 2 Gambarsari pada mata pelajaran IPS materi Kegiatan ekonomi masyarakat masih rendah, hal tersebut dikarenakan peneliti belum menerapkan metode demonstrasi dalam pembelajaran. Pada pembelajaran pra siklus diperoleh hasil ketuntasan hanya mencapai 13 persen yaitu hanya 2 anak yang tuntas KKM dari 15 anak yang ada. Sementara pada pembelajaran siklus 1, peneliti sudah menerapkan metode demonstrasi dalam pembelajaran pada pembelajaran IPS materi kegiatan ekonomi masyarakat, sehingga pada siklus 1 sudah menunjukan adanya peningkatan sebesar 27 persen sehingga pada siklus 1 tingkat ketuntasan mencapai 40 persen dan ada 5 siswa yang tuntas KKM. Meskipun pada siklus 1 menunjukan adanya peningkatan namun peningkatan tersebut masih jauh dari harapan peneliti. Sementara itu hasil pengamatan yang diperoleh pada siklus 2 menunjukan adanya peningkatan lagi dari pada sebelumnya, peningkatan tersebut menurut peneliti cukup signifikan karena hasil pengamatan menunjukan peningkatan hingga 93 persen atau dengan kata lain ada 14 siswa yang tuntas KKM sehingga hanya menyisakan 1 anak yang belum tuntas KKM pada mata pelajaran IPS materi kegiatan ekonomi masyarakat. Peningkatan tersebut terjadi karena peneliti selain mendemonstrasikan video tentang kegiatan ekonomi masyarakat, peneliti juga meminta siswa untuk mempraktekan 3 kegiatan ekonomi yang dilakukan masyarakat seperti kegiatan produksi, kegiatan distribusi dan kegiatan konsumsi. Dengan metode demonstrasi yang diterapkan oleh peneliti tersebut siswa terlihat begitu antusias dalam pembelajaran, hal tersebut dapat terlihat dari keaktifan siswa selama pembelajaran berlangsung, siswa merasa tertarik dan senang dengan adanya video yang didemontrasikan oleh peneliti, karena ketertaikanya tersebut siswa menjadi begitu mencermasti isi dari video tersebuy yang dimana berisi tentang kegiatan ekonomi masyarakat, dengan adanya demonstrasi video tersebut peneliti tidak perlu menjelaskan panjang lebar tentang kegiatan ekonomi masyarakat dikarenakan siswa sudah terlihat memahami dan mengerti tentang materi tersebut. Meskipun pada siklus 2 peningkatan hasil belajar IPS materi tentang kegiatan ekonomi masyarakat mencapai 93 persen namun hal tersebut tidak membuat peneliti merasa puas, sehingga peneliti melanjutkan ke siklus berikutnya yaitu siklus 3 dengan harapan hasil belajar siswa kelas IV SDN 2 Gambarsari akan dapat meningkat hingga 100 persen.

Dalam siklus 3 ini, peneliti masih menerapkan metode demonstrasi dalam pembelajaran dengan harapan akan terjadi peningkatan hasil belajar hingga 100 persen. Peneliti mendemonstrasikan video tentang kegiatan ekonomi masyarakat yang meliputi tiga 
kegiatan produksi, distribusi dan konsumsi. Pada siklus 3 ini keaktifan siswa terlihat meningkat, hal tersebut terbukti dengan banyaknya siswa yang aktif dalam pembelajaran dengan mengajuakan pertanyaan kepada peneliti, namun peneliti tidak serta merta menjawab pertanyaan dari siswa, untuk lebih mengetahui apakah siswa sudah memahami materi IPS materi tentang kegiatan ekonomi masyarakat maka peneliti melemparkan pertanyaan yang ditanyakan oleh siswa kepada siswa lain, dengan harapan siswa yang lain dengan suka rela dapat menjawab pertanyaan tersebut. Dan ternyata pada siklus 3 ini harapan peneliti tercapai karena ternyata banyak siswa yang mengajukan diri untuk menjawab pertanyaan dari temanya, melihat hal tersebut akhirnya peneliti membuka berbagai pertanyaan dari siswa dan mempersilahkan siswa yang lain untuk menjawab pertanyaan yang diajukan temanya. Dengan demikian pada siklus 3 ini pembelajaran begitu aktif dan komunikatif, hal tersebut dikarenakan bukan hanya terjadi interaksi anatara siswa dengan guru melainkan interaksi siswa dengan siswapun terlihat begitu nyata dan begitu antusias. Kemudian Setelah pelaksanaan siklus 3 dilaksanakan maka penelti dan observer menagdakan refleksi untuk mengetahui hasil dari pelaksanaan siklus 3 . Setelah diperoleh hasil penelitian pada siklus 3 ini maka peneliti merasa puas, karena ternyata hasil penelitian pada siklus 3, menunjukan adanya peningkatan yang sesuai dengan harapan peneliti yaitu hasil belajar siswa mencapai 100 persen. Dengan demikian dari 15 siswa yang ada semuanya tuntas KKM pada mata pelajaran IPS materi tentang kegiatan ekonomi masyarakat.

Melihat adanya peningkatan pada siklus 3 yang menunjukan hasil belajar siswa kelas IV SDN 2 Gambarsari menunjukan peningkatan hingga 100 persen, hal tersebut membuktikan bahwa penerapan metode demonstrasi dapat menigkatkan hasil belajar siswa kelas IV SDN 2 Gambarsari materi tentang kegiatan ekonmi masyarkat. Selain hasil belajar yang meningkat ternyata penerapan metode demonstrasi juga dapat meningkatkan keaktifan siswa dalam pembelajaran IPS materi tentang kegiatan ekonomi masyarakat. Dengan demikian maka penerapan metode demonstrasi dapat meningkatkan hasil belajar dan keaktifan siswa kelas IV SD Negeri 2 Gambarsari Kecamatan Kebasen Kabupaten Banyumas pada tahun ajaran 2020/2021.

\section{SIMPULAN}

Berdasarkan penelitian tindakan kelas yang dilakukan di SD Negeri 2 Gambarsari Kecamatan Kebasen Kabupaten Banyumas dapat disimpulkan bahwa penggunaan metode demonstrasi dan media miniatur dapat meningkatkan hasil belajar IPS materi kegiatan ekonomi di masyarakat. Peningkatan hasil belajar ditandai dengan nilai siswa yang mencapai KKM sebesar 75, yakni pada pra siklus nilai dari 15 siswa diketahui hanya $2(13 \%)$ siswa yang tuntas. Kemudian pada siklus I meningkat menjadi $6(40 \%)$ siswa yang tuntas. Pada siklus II mengalami peningkatan yaitu sebanyak 14 (93\%) siswa tuntas. Dan pada siklus III hasil belajar meningkat dari 14 (93\%) siswa yang tuntas menjadi $15(100 \%)$ siswa yang tuntas.

Berdasarkan kesimpulan di atas, hal-hal yang perlu diperhatikan bagi guru adalah hendaknya guru lebih kreatif dalam mengemas pembelajaran agar siswa tidak mudah bosan pada saat pembelajaran berlangsung, serta mengikut sertakan siswa dalam proses pembelajaran. Sementara hal-hal yang harus diperhatikan bagi siswa adalah Siswa diharapkan untuk lebih aktif dalam mengikuti pembelajaran yang disampaikan oleh guru sehingga hasil belajarnya dapat meningkat. Kemudian bagi pihak sekolah sebaiknya mengadakan pembinaan terhadap guru untuk melatih guru terutama pembinaan tentang bagaimana guru harus mengemas pembelajaran, karena jika guru berhasil mengemas pembelajaran dengan menarik maka siswa akan lebih tertarik dan lebih memperhatikan pada saat proses pembelajaran. 
SHEs: Conference Series 3 (3) (2020) 449-454

DAFTAR PUSTAKA

Kunandar. 2011 Langkah mudah Penelitian Tindakan Kelas sebagai pengembangan

Profesi Guru. Jakarta: Raja Grafindo Persada. 
